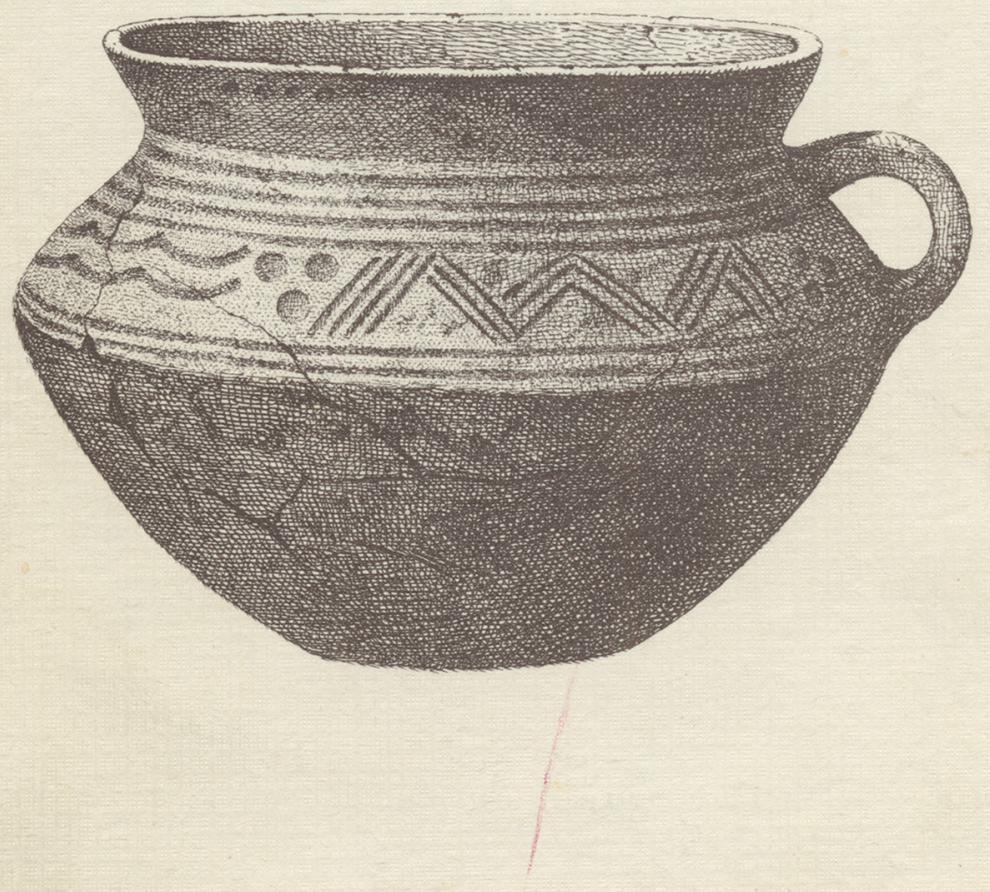




\section{KUML}

\section{ÅRBOG FOR JYSK ARKÆOLOGISK SELSKAB 1959}

With Summaries in English

Mit deutschen Zusammenfassungen

JYSK ARKÆOLOGISK SELSKAB

SATTE DETTE KUML

FOR

GUDMUND HATT

på 75-årsdagen 31. oktober 1959

UNIVERSITETSFORLAGET I AARHUS

1959 
Forside:

Udsnit af træportal fra Hylestad kirke, Setesdal, Norge.

Redaktion:

P. V. G L O B

Copyright 1959

by

Jysk Arkæeologisk Selskab

Printed in Denmark

by

Aarhuus Stiftsbogtrykkerie A/S

Clichéer:

Hammerschmidt - Århus

F. Hendriksens Reproduktionsatelier - København 


\section{N D H O L D}

Johannes Brøndsted: Gudmund Hatt $\ldots \ldots \ldots \ldots \ldots \ldots \ldots \ldots \ldots \ldots \ldots$

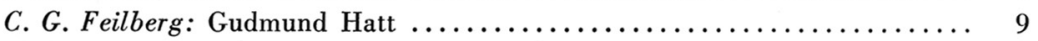

Niels Thomsen: Hus og kælder i romersk jernalder $\ldots \ldots \ldots \ldots \ldots \ldots \ldots . .13$

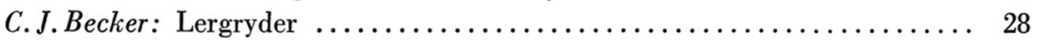

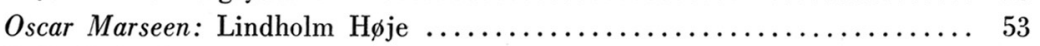

P.V.Glob: Avlsten ................................. 69

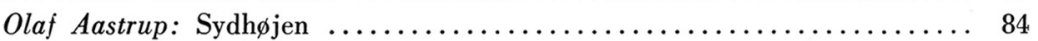

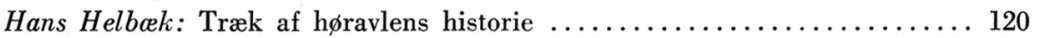

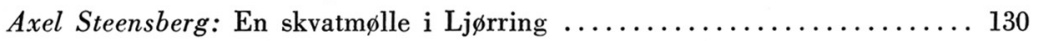

Werner Jacobsen: Nepalesiske bloktryk ..................... 146

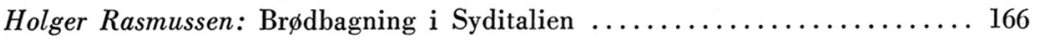

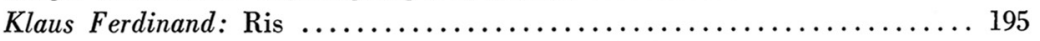

P.V.Glob: Arkæologiske unders $\emptyset$ gelser i fire arabiske stater .......... 233

Jysk Arkæologisk Selskab . ........................... 240

Bibliografi over arkæologiske og kulturgeografiske skrifter m. fl. af Gud-

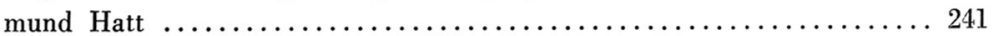

\section{G ON T E N T S}

Johannes Brфndsted: Gudmund Hatt $\ldots \ldots \ldots \ldots \ldots \ldots \ldots \ldots \ldots \ldots \ldots . \quad 8$

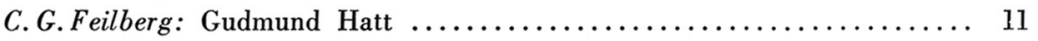

Niels Thomsen: Cellar and House in the Roman Iron Age ........... 25

C.J.Becker: Eisenzeitliche Tontöpfe mit Innenhenkeln oder »Schwalbennest-

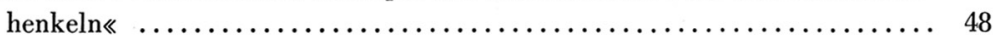

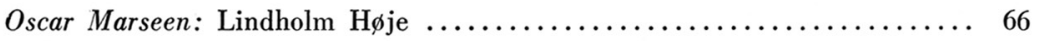

P.V.Glob: Forge-stones-New Types from the Danish Iron Age ........ 80

Olaf Aastrup: The South Mound at Jelling .................... 100

Hans Helbaek: Notes on the Evolution and History of Linum . . . . . . . 103

Axel Steensberg: A Horizontal Mill at Ljørring, Jutland ............. 142

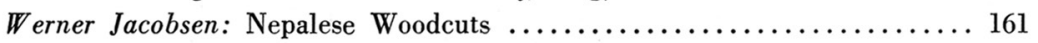

Holger Rasmussen: The Baking of Bread in Southern Italy ............. 187

Klaus Ferdinand: Rice - Aspects of Cultivation and Treatment in East

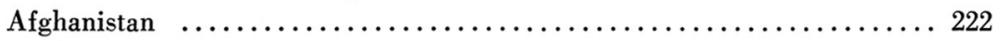

P. V. Glob: Archeological Investigations in Four Arab States .......... 238

Bibliography of Archeological and Cultural Geographical Papers by Gud-

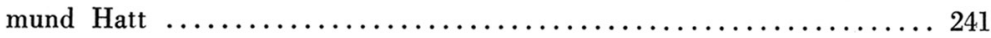




\title{
NEPALESISKE BLOKTRYK
}

\author{
Glimt af Nepals kunsthåndvark og religion.
}

\author{
Af WERNER JACOBSEN
}

Når vi her taler om Nepal, forstår vi dermed ikke landet Nepal, som det i dag fremtræder på kortet; men det meget frugtbare dalstrøg, Himalayaområdets st $\varnothing$ rste, som er sæde for landets hovedstad, Kathmandu. Ikke alene er i gammel tid betegnelsen, Nepal, synonym med Kathmandudalen; men op til vore tider er for de omboende bjergfolk Nepal stadig enstydig med Kathmandudalen med dens urbane civilisation. Politisk er denne begrænsning af begrebet, Nepal, forvirrende, for »Dalen « med sine ca. 565 kvadratkilometer udg $\varnothing \mathrm{r}$ mindre end en halv procent af det uafhængige konged $\varnothing$ mmes totale område, og der har været tidspunkter i landets historie, hvor endnu større områder var under dalens kontrol. Kulturhistorisk set er vi imidlertid på logisk grund, for ikke blot var det i Kathmandudalen, at landets højere kultur udviklede sig, men den bredte sig ikke på noget tidspunkt i nævneværdig grad udover de afgrænsende bjergrygge. Kunne dette forhold forekomme mærkeligt, kan der peges på, at det faktisk på forhånd var dikteret af de geografiske betingelser. For bjergsamfundene, som grundet på fraværelsen af naturlige muligheder ikke kunne gøre sig håb om at udvikle sig udover et lavt stadie af selvforsynende eksistens, baseret på et primitivt agerbrug og kvæghold, var der lidet at hente i Kathmandudalens drivhuskultur, der med held kunne omplantes i bjergområdernes barske klima.

Fra det tidspunkt hvor Manjusri med sit sværd kløvede klippen i Chovar, og derved afdrænede den s $\varnothing$, der if $\varnothing$ lge folketraditionen hidtil havde fyldt dalen, har de rige leraflejringer hjulpet af et ideelt klima og flittige bondehænder, årligt afgivet to til tre afgrøder. Med udgangspunkt $\mathrm{i}$ denne naturlige frodighed udvikledes i Kathmandudalen en høj kultur, der bestandig næredes af de to store asiatiske kulturer, den indiske og den kinesiske, et forhold der umiddelbart medførte, at den nepalesiske civilisation samtidig kom til at spille en vigtig rolle som formidler af kulturimpulser mellem disse rige kulturcentre. Dette i sig selv er af største kulturhistorisk interesse; men må dog tage andenpladsen i sammenligning med de ikke få tilfælde, hvor den nepalesiske civilisation var i stand til at yde sit eget originale bidrag til asiatisk kulturudvikling; bidrag, der med iver blev absorberet af de andre asiatiske civilisationer.

Man må nødvendigvis undre sig over, hvorledes en højtstående kultur kunne udvikle sig på et så begrænset område, for hvor frugtbar end den gamle søbund var, og med hvor stor en dygtighed den end blev kultiveret, må den nepalesiske kultur dog have hvilet på en meget bredere $\varnothing$ konomisk basis, end den agerbruget 


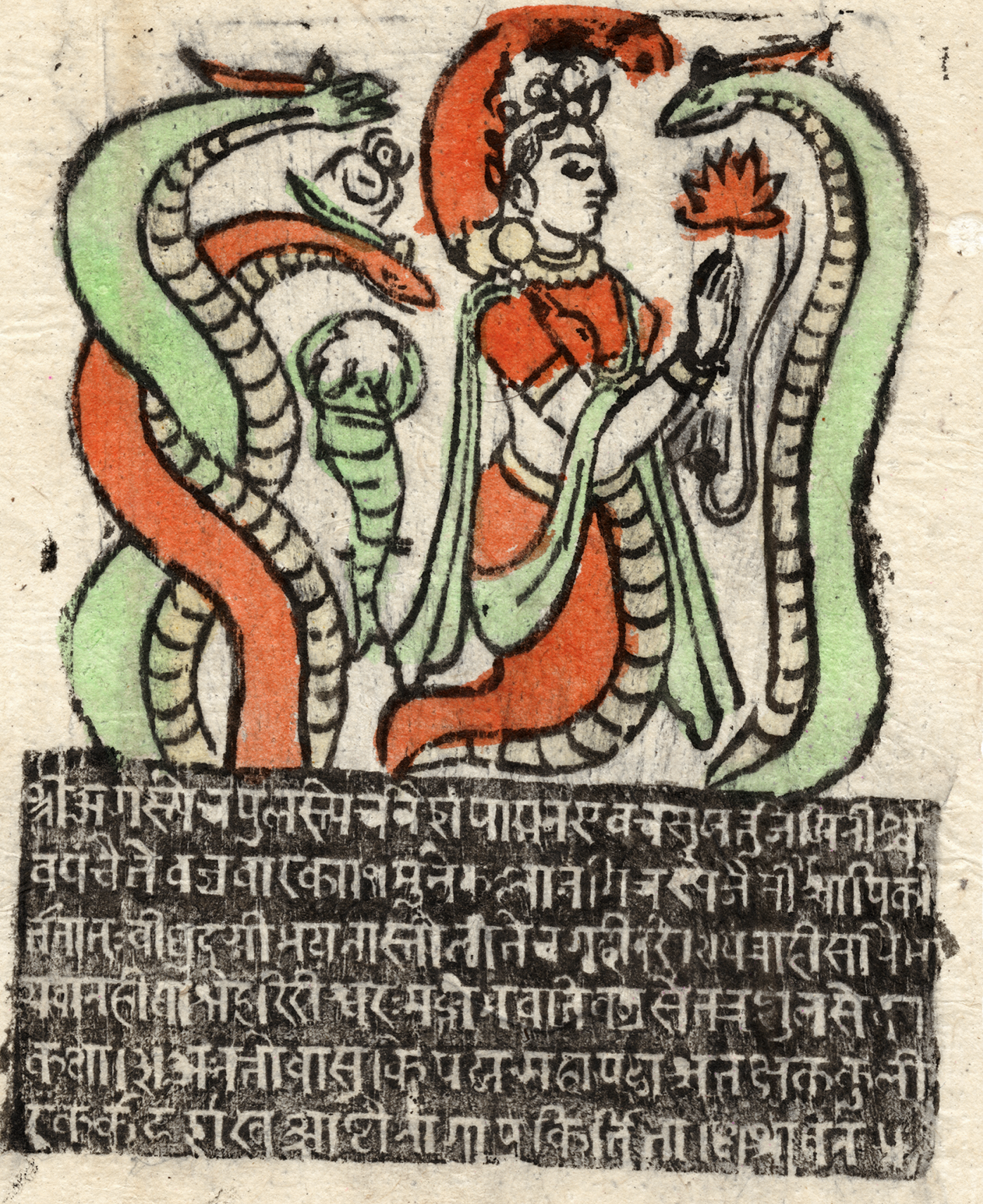

Fig. 1. Originalt bloktryk fra Kathmandu. Det benyttes i forbindelse med den årlige fest for slangerne, Naga Panchami. Trykket er på det lokale, håndgjorte papir, der nu næsten helt er erstattet af indført, fabriksfremstillet papir.

Original woodcut from Kathmandu. It is used in the annual snake-festival, Naga Panchami. It is blockprinted on the local hand-made paper, which has now been almost entirely replaced by imported factorymade paper. 


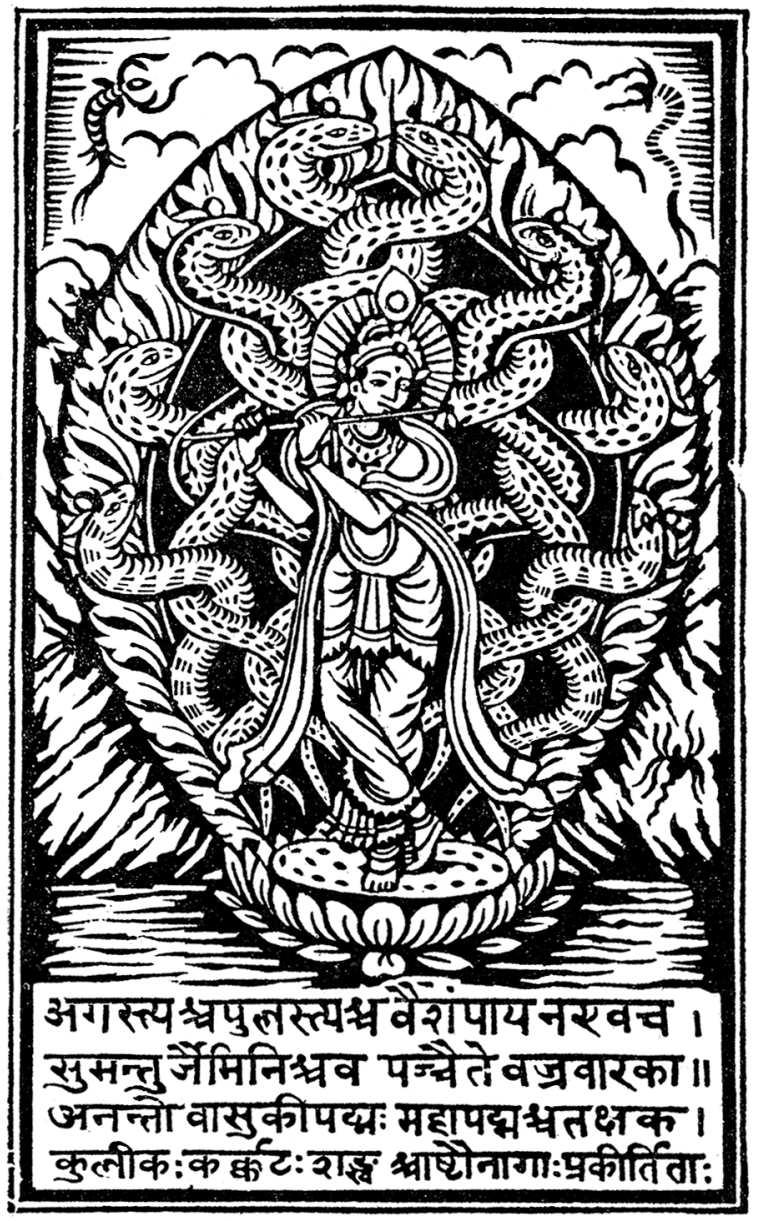

Fig. 2. Den fløjte-spillende Krishna med de otte Naga-konger. Bloktryk fra Kathmandu, $12 \mathrm{~cm} \times 7,5 \mathrm{~cm}$.

Krishna playing on his flute, and the eight Naga-kings. A woodcut from Kathmandu, $12 \mathrm{cms} . \times 7.5 \mathrm{cms}$.

kunne yde. Bjergområderne har næppe på noget tidspunkt i nævneværdig grad bidraget til dalens $\varnothing$ konomi, og skønt lavlandet syd for bjergene, Terai, med dets vidtstrakte agerbrugsområder teoretisk kunne have været en vigtig $\varnothing$ konomisk faktor i Kathmandudalens velstand, har dette i praksis næppe været tilfældet. Dels var dalens politiske kontrol af Terai-områderne kun periodevis, dels kan det ikke på noget tidspunkt have været et særlig indbringende foretagende at fors $\varnothing$ ge på at afskære de lette og naturlige forbindelseslinier mod syd, og erstatte dem med de besværlige bjergstier, der førte mod dalen. Vi bringes derfor til den konklusion, at de ressourcer, på hvilke den nepalesiske kultur opbyggedes, i det væsentlige fandtes indenfor selve dalens område. Men hvor finder vi dem?

Selv en overfladisk betragtning af livet $\mathrm{i}$ dalen, som det former $\operatorname{sig} \mathrm{i}$ dag, giver et næsten overvældende indtryk af kunsthåndværkets betydning. Forfædrenes og nutidens bidrag er repræsenteret side om side ved de utallige templer, klostre og paladser med rigt udskåret og bemalet træværk, portaler og facader 


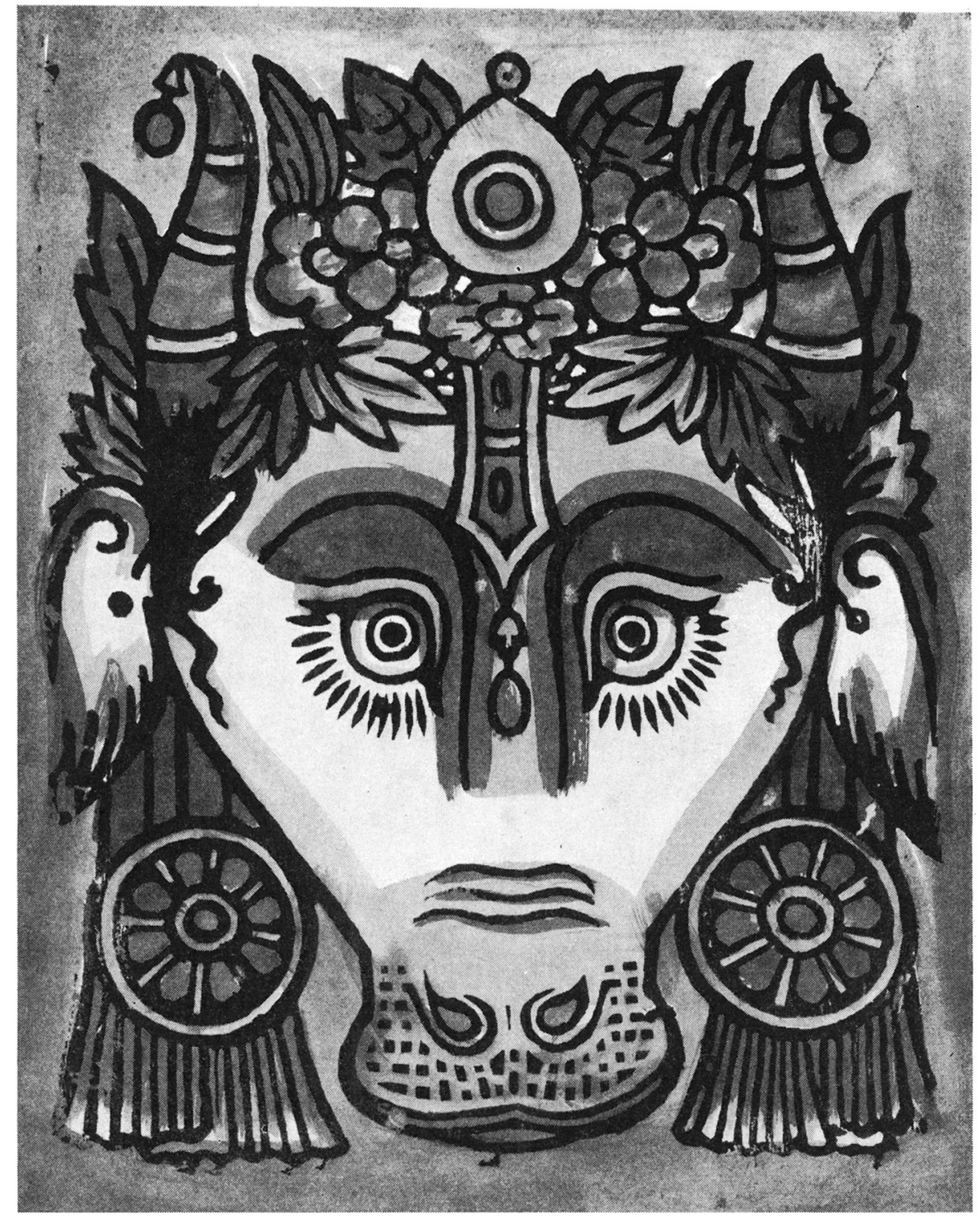

Fig. 3. Kohovede, der benyttes i dødekulten, Gaii Jatra. Farvelagt bloktryk fra Kathmandu, $28 \mathrm{~cm} \times 23 \mathrm{~cm}$. Cow's head, used in the cult of the dead, Gaii Jatra. Coloured woodcut from Kathmandu, $28 \mathrm{cms} . \times 23 \mathrm{cms}$.

dækket af drevne og ciselerede metalplader af sølv eller forgyldt kobber, skulpturer i metal, sten og terracotta, malerier. Hvad der er endnu mere forbavsende er, at det rige nepalesiske kunsthåndværk, som det så ofte var tilfældet i de asiatiske kulturer, ikke var reserveret til brug for de religiøse institutioner og den privilegerede overklasse. I borgerens hus brydes de monotone murstensflader af rigt udskårne vinduer, søjler og dørfyldninger, teen drikkes af ciselerede sølvkopper, 


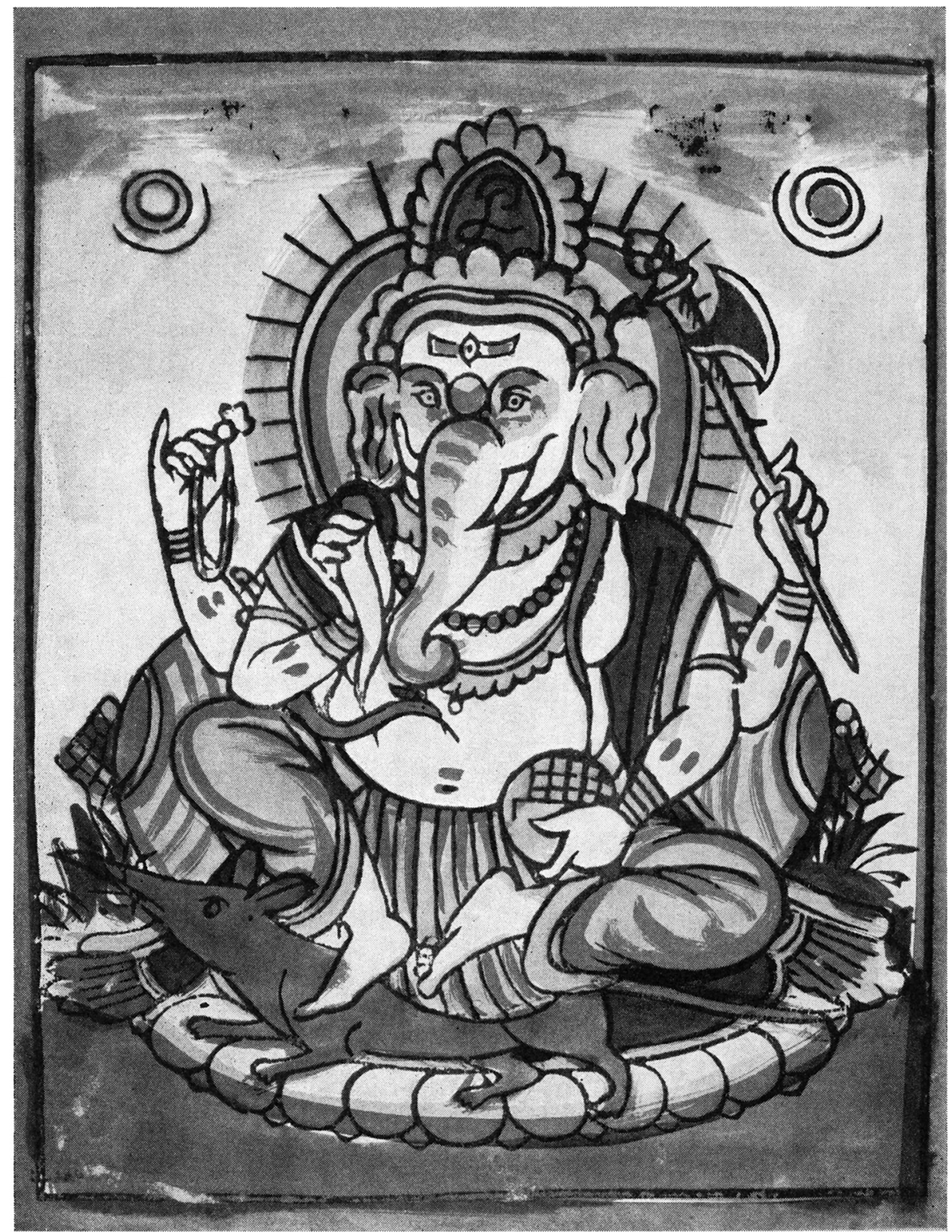

Fig. 4. Ganesha, visdommens gud. Fra Gaii Jatra ceremonien. Farvelagt bloktryk fra Kathmandu, $24 \mathrm{~cm} \times 19 \mathrm{~cm}$.

Ganesha, god of wisdom. From the Gaii Jatra ceremony. Coloured woodcut from Kathmandu, $24 \mathrm{cms} . \times 19 \mathrm{cms}$. 
og risbrændevinen skænkes fra elegant formede og ornamenterede bronzeflasker; og når solen forsvinder bag bjergene ved Thankot tændes vægen $\mathrm{i}$ de smukke bronzelamper i og udenfor huset. Selv til bønderne ude i dalen har kunsthåndværket spredt sig, for når bondekonen starter processer, der resulterer i bondens hjemmevævede trøje, stribede vest og de fantastiske pludderbukser, spinder hun garnet på et smukt udskåret spindehjul. Dette er ikke, som vi kender det fra Europa, skåret af manden i de lange vinteraftener; men er et produkt af den professionelle kunstindustri i byerne.

En vandring over de toppede brosten gennem de middelalderlige gyder i dalens større byer, Kathmandu, Lalitpur (Patan) og Bhaktapur (Bhadgaon) konfronterer os med et imponerende antal af flittigt arbejdende kunsthåndvær-

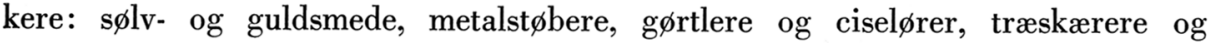
malere. Alt i alt efterlades et stærkt indtryk af den betydelige position som kunsthåndværket indtager $\mathrm{i}$ dalens liv. At dette yderligere ikke er nogen ny foreteelse vidner de gamle, rigt udstyrede templer og paladser om; men i det store og hele fører disse os kun nogle få århundreder tilbage. Desværre er vor viden om Nepals historie mangelfuld, så i de fleste tilfælde kan den ikke bidrage med sikker vejledning udover om forhold og tildragelser i den nyere tid; men vi får i dette tilfælde en uventet støtte udefra. I det kinesiske Yuan dynasti's kroniker omtales det, at kejseren i år 1260 udstedte ordrer til, at storlamaen af Tibet, Phags-pa, skulle bygge en gylden pagode. For at udføre denne ordre indkaldte Phags-pa nepaleseren, Arniko, der med et følge på 80 nepalesiske håndværkere og kunstnere ankom til Tibet. Efter fuldførelsen af pagoden i Tibet, kaldtes Arniko i 1263 til Kublai Khan's hof, hvor han i de følgende år opnåede et enestående ry for metalst $\varnothing$ bninger, maleri på silke og andre kunsthåndværk. Seks århundreder forud for Yuan kronikens tribut til nepalesisk kunsthåndværk omtaler den kinesiske rejsende, Hsuan Tsang, at der i Nepal findes r $\varnothing \mathrm{dt}$ kobber, at dette metal bruges til mønter, og at nepaleserne er dygtige kunstnere. Ihukommende det overordentlige høje stade på hvilket Kinas egen kunstindustri befandt sig, må de to kinesiske referencer til nepalesisk kunstnersnille tages som udtryk for den højeste udmærkelse. Da vi yderligere er oplyst om, at det for metal-kunstindustrien værdifulde materiale, kobber, fandtes i Nepal, og at nepalesisk kunsthåndværk var værdsat og søgt langt udenfor dalens område, kan det næppe betragtes som en uoverlagt antagelse, at vi her er fundet frem til en af de væsentlige faktorer bidragende til den nepalesiske civilisations trivsel. De nepalesiske kunsthåndværk smykkede deres eget samfund; men det var samtidig en efters $\varnothing \mathrm{gt}$ eksportvare, som bragte rigdomme hjem til dalen og derved skabte den $\phi$ konomiske mulighed for dannelsen af en højtudviklet kultur.

Der er andet foreliggende materiale, der bekræfter denne antagelse; men det har her kun været formålet, indledningsvis at give baggrund for en placering af det nepalesiske kunsthåndværk, da vort egentlige emne er hentet fra dette rige område.

Det er bedre sagt med det samme, at bloktrykkene på ingen måde er gyldige udtryk for det nepalesiske kunsthåndværks fortræffelighed. Snarere repræsenterer de dettes laveste stade, og når de her er valgt som emne, skyldes det først og fremmest, at de i kampen med moderne trykkemaskiner står overfor et umiddel- 
bart nederlag og total udslettelse. Dernæst at de giver et levende indtryk af det religiøse liv, som det former sig blandt almenbefolkningen i Kathmandudalen.

Bloktrykkene er, med få undtagelser, knyttede til de religiøse fester og ceremonier, og vi skal derfor i det følgende give en beskrivelse af nogle af de vigtigste.

Hvert år afholdes på den femte dag i den lyse halvdel af måneden, Srawan, en fest til ære for Naga'erne, slangerne. Denne fest kaldes Naga Panchami, og faldt i 1958 ifølge vor kalender på den 19. august. Den nepalesiske kalender er baseret på et måneår, og der indtræffer derfor fra år til år forskydninger i forhold til vor tidsregning.

If $\varnothing$ lge det buddhistiske skrift, „Kriya Samuchchaya", siger Buddha: »Tilbed Nagaerne, og også Varuna, på den femte dag i den lyse halvdel af Srawan. Dette modvirker alt djævelskab forårsaget af slangerne og befordrer en rigelig nedbør! « Hinduernes autoritet er skriftet, "Garuda Tantra« i hvilket Vishnu påbyder: »Klæb med kogødning billeder af Nagaerne over husets indgang og de andre døre i huset på den lyse halvdels femte dag i måneden, Srawan, og tilbed slangerne i overensstemmelse med det nedlagte ritual «.

I overensstemmelse med disse forskrifter observeres denne »slangedag " af både hinduer og buddhister, og større og mindre farvelagte bloktryk fremstillende Nagaer klæbes over husets indgang og de andre døre i huset. Denne type af bloktryk er her repræsenteret ved originaltrykket fig. 1, fremstillende Kanya Nagini, Slangejomfruen, et særligt yndet emne indenfor denne gruppe af bloktryk. Denne figurs popularitet skyldes sikkert, at hun er slangeverdenens modstykke til menneskeverdenens Kanya Kumari, hvis dyrkelse er specielt udviklet i Nepal. Kanya Kumari er den guddommelige jomfru, en form af Parvati, der i Nepal er repræsenteret ved flere levende personifikationer, hvoraf den dødsensalvorlige lille Kumari, der residerer i sit eget paladstempel overfor det gamle kongelige palads i Kathmandus center, betragtes som den fornemste. Efter en noget grusom udvælgelsesprocess installeres den nye Kumari, i reglen i 5-6 års alderen, og hun holder sin guddommelige position til pubertetens indtrædelse, hvorefter en ny Kumari udvælges.

Sanskrit teksten på bloktrykket, fig. 1, er en lidt forkortet form af en standardtekst, som helt eller i uddrag i reglen findes på nagatrykkene. Efter et præfiks, påkaldende Ganesha, elefantguden, der sædvanligvis indleder de religiøse tekster, siger den i sin komplette udgave: "Helgenerne Agastya, Pulastya, Vaisampayam, Sumanta og Jaimini er de fem beskyttere af tordenkilen. Der er otte Nagaer, hvis navne er Ananta, Vasuki, Padma, Mahapadma, Tahshaka, Kulika, Karkotaka og Sankha«.

Ifølge "Vishnu Purana « var Kadru en af Kasyapas tretten koner, og en sønnedatter af Brahma, moder til tusind, mangehovede slanger, som var organiserede under tolv høvdinge. Andre tekster omtaler, som vor, otte vigtige Nagaer. Slangesamfundene bebor underverdenen, have og søer sammen med skorpioner, tusindben og andet kryb.

Hindumytologien er fuld af beretninger om de magtfulde, men underfundige Nagaer, som det er bedre at holde sig gode venner med, og for Kathmandudalens befolkning er de mytologiske beretninger af speciel frygtindgydende nærhed, for i den lokale "Swayambhu Purana" berettes det, at søen, der før fyldte dalen, 


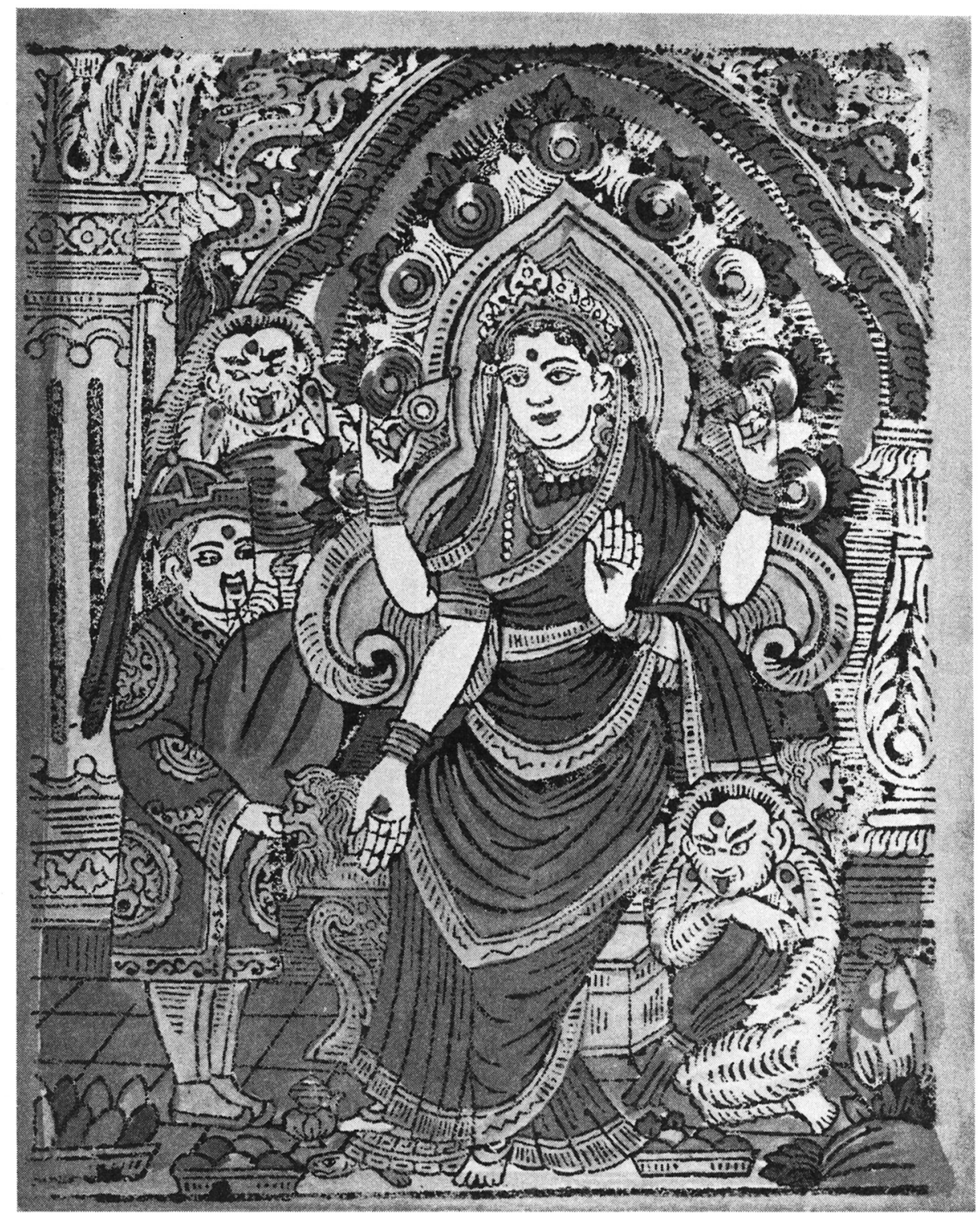

Fig. 5. Lakhsmi, rigdommens gudinde. Farvelagt bloktryk til påklæbning på pengekisten under Lakhsmi Puja. Antagelig fra Lalitpur, $20 \mathrm{~cm} \times 16 \mathrm{~cm}$.

Lakhsmi, goddess of riches. Coloured woodcut for pasting on cash-boxes during the Lakhsmi Puja. Probably from Lalitpur, $20 \mathrm{cms} . \times 16 \mathrm{cms}$. 


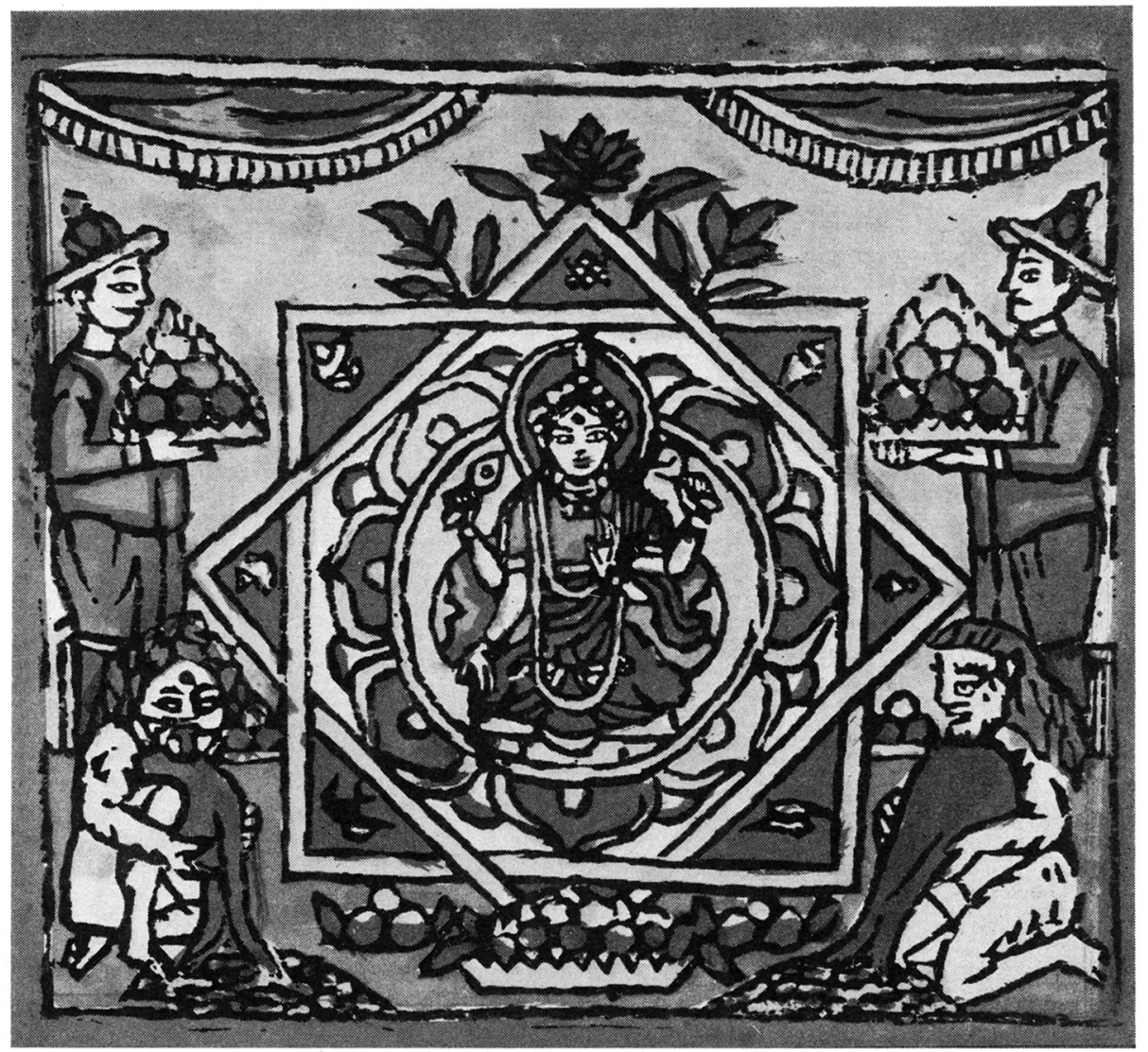

Fig. 6. Lakhsmi Mandala. Anvendes i forbindelse med Lakhsmi Puja. Farvelagt bloktryk, $12 \mathrm{~cm} \times 13 \mathrm{~cm}$. Lakhsmi Mandala, used in connection with the Lakhsmi Puja festival. Coloured woodcut, $12 \mathrm{cms} . \times 13 \mathrm{cms}$.

var beboet af Karkotaka Naga og mange andre slanger. Man lever derfor i en konstant bevidsthed om at have fordrevet disse farlige væsener fra et yndet tilholdssted, og må derfor gøre sig ganske specielle anstrengelser for at genoprette det gode forhold.

Som naturligt er, hvor en talrig befolkning lever på et meget begrænset agerbrugsområde, er dalens fødevaresituation det altoverskyggende problem. Som den citerede tekst fra "Kriya Samuchchaya" antyder, er man sig sørgeligt bevidst, at Nagaerne, om ikke pacificerede, er tilbøjelige til at ramme det svageste punkt: de kan afskære dalen fra det livgivende regnfald, uden hvilket der kun vil være sult og elendighed. Set på denne baggrund kan det ikke undre, at der i begyndelsen af den lyse halvdel af måneden Srawan, er ivrig efterspørgsel på bloktrykkene, der fremstiller de forskellige nagapersonligheder, og at disse, som de gamle skrifter påbyder, på den femte dag med omhu klæbes over alle døre.

I denne landsomfattende udstilling af slangeportrætter ses ofte den populære gudehelt, Krishna. Som så ofte, hvor fri menneskelig udfoldelse var i fare, er han 
kommet til undsætning. Med sit fløjtespil fortryller han de otte, farlige slangekonger, der bundet $\mathrm{i}$ et fast sammentømret, geometrisk system udligner hinandens kræfter og derved bliver ufarlige for menneskeheden. Denne scene er her repræsenteret ved det smukke træsnit gengivet som fig. 2 .

Året igennem er porten til nepalesernes himmel, Yama Dwar, lukket, og man må formode, at mellem det stadigt stigende antal af afdøde, der venter udenfor, imødeses den ene dag om året, hvor porten står lidt på klem, med største forventning. Denne dag falder på den første dag af den mørke halvdel af måneden Srawan (i 1958 d. 30. august).

Uheldigvis for de døde åbnes porten ikke så meget, at de kan slippe ind, og erfaringen viser, at kun koen ved at skubbe med sine horn er i stand til at bevæge den tunge port. Det er for at hjælpe på denne uheldige situation, at Gaii Jatra (Sa-Paru på Newari) ceremonien observeres på denne dag. Hver familie, i hvilken dødsfald fandt sted i det forløbne år, sender en ko, eller et af familiens medlemmer forklædt som ko for at hjælpe den afdøde ind $i$ himlen.

Grundlaget for denne ceremoni er overalt i dalen det samme, kun den ydre form varierer en smule fra sted til sted. Til forklædning som ko anvendes i Kathmandu et hovedt $\varnothing j$ bestående af en flad, flettet kurv, der på forsiden er forsynet med et farvelagt bloktryk af et kohovede (fig. 3), på bagsiden et tryk af Ganesha, (fig. 4). På hver side af hovedtøjet er der en tynd opstander af træ eller bambus med farvestrålende papirsflag og vifteformede dekorationer, ligesom der på kurven findes anbragt et samlet bundt af tre miniature kohorn i flettet strå, hvis betydning ikke har kunnet opspores. Den forklædte person trækker et langt klæde efter sig, hvorpå der anbringes gaver til den afdøde $\mathrm{i}$ form af frugter og kager. I Kathmandu afholdes Gaii Jatra som et familieforetagende, og separate processioner bestående af forklædte køer, og for de mere velhavende familiers vedkommende også rigtige køer, drager igennem byen ledsaget af fløjtespil og trommer. I Lalitpur (Patan) derimod, samles alle deltagere i een stor procession, der ledsaget af mange orkestre, drager de afdøde til undsætning, og her trækker »køerne" efter sig potter, pander og andet husgeråd.

I Bhaktapur (Bhadgaon) er ceremonien noget forskellig. Der fyldes en stor rund kurv kaldet Doko, med tøj. Den vendes med åbningen nedad, og på toppen anbringes to kohorn af flettet strå. Herunder anbringes, som i Kathmandu, et tryk af et kohovede på forsiden, et af Ganesha på bagsiden. Den dekorerede kurv tages nu til præsten, der »læser over den«, hvorefter en person engageres til for betaling at vandre rundt $\mathrm{i}$ byen med kurven over hovedet. I Bhaktapur er det ikke ualmindeligt at se endnu mere imponerende »køer". Disse er fremstillet over et skelet af lange bambus, og er ofte så store, at der må adskillige personer til at bære dem rundt i procession.

Af alle de mange forskellige motiver det nepalesiske bloktryk behandler, er kohovedet til brug i Gaii Jatra ceremonien af den højeste dekorative virkning (fig. 3). Blokken er skåret med stærke, kraftige linier, og farvelægningen foretaget med sikker sans for dramatiske farveklange. At vi finder elefantguden, Ganesha (fig. 4), som deltager i denne ceremoni kan ikke forundre, for Siva og Parvatis søn er simpelthen allesteds nærværende i Nepal. Ingen fest fejres, ingen ceremoni afholdes uden hans nærværelse; og hvor kan hans bistand være mere $\varnothing$ nskværdig, 


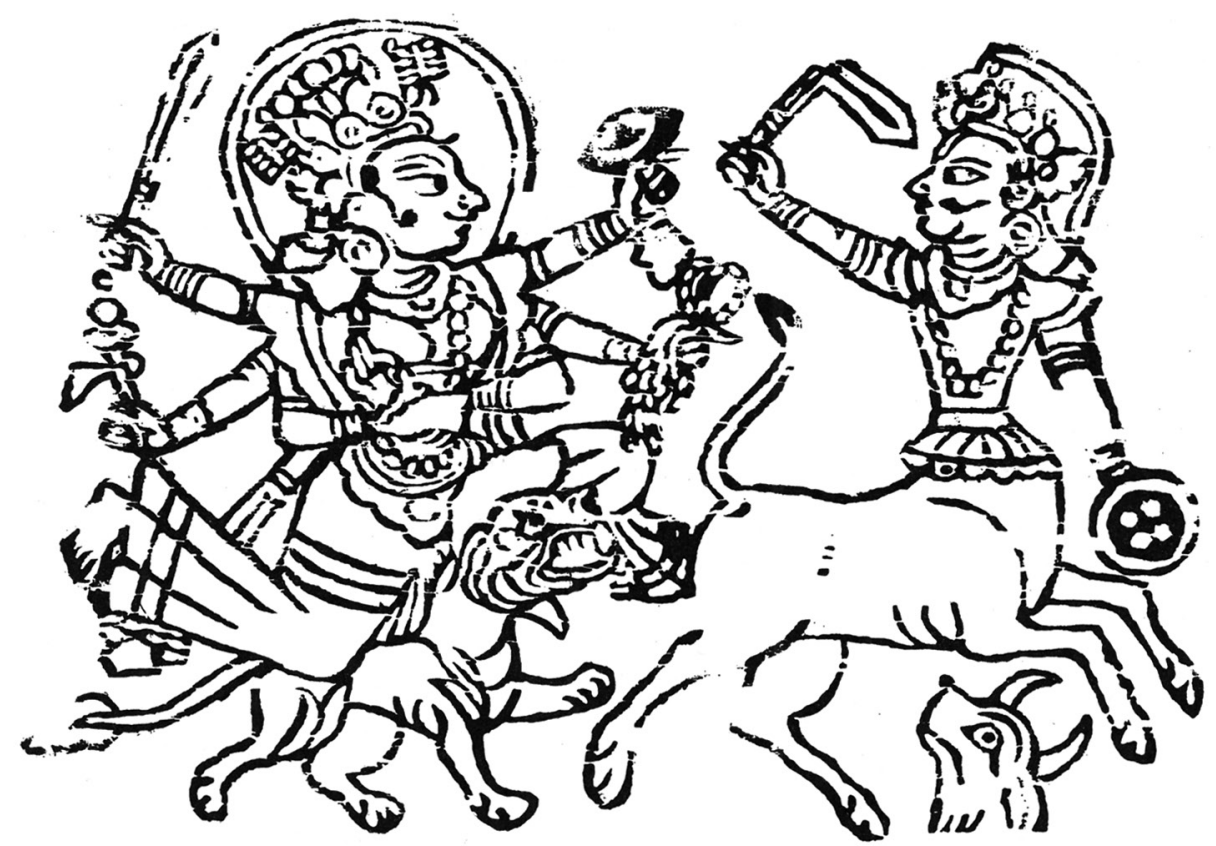

Fig. 7. Durgas kamp med bøffeldjævelen Mahishasura. Aftryk af gammel blok fra Bhaktapur, $18 \mathrm{~cm} \times 25 \mathrm{~cm}$.

Durga's fight with Manishasura, the buffalo devil. Print of an old block from Bhaktapur, $18 \mathrm{cms} . \times 25 \mathrm{cms}$.

end når det drejer sig om at hjælpe en kær afdød, måske ikke helt selvfortjent, ind gennem himlens port. For Ganesha, visdommens gud, er også forhindringernes overvinder.

Det siges, og ikke ganske med urette, at i Nepal har hver dag i året sin egen fest eller ceremoni; men næppe nogen begivenhed imødeses med større udelt glæde, end den årlige ceremoni for rigdommens gudinde, Lakhsmi. For Lakhsmi Puja er en rigtig fest, helt uden den nagende frygt som Naga Panchami og mange af de andre ceremonier er baseret på, uden det vemodige minde om den afdøde, som er knyttet til Gaii Jatra og fri for det makabre og bekostelige element, der knytter sig til festerne, hvor blodofre er påkrævet.

Ifølge skriftet, "Padma Purana", har Brahma fastlagt datoen for Lakhsmi Pujas afholdelse: den femtende dag i den mørke halvdel af måneden, Kartic (i 1958 d. 11. november); medens ritualet er nedlagt i et andet skrift, "Lakhsmi Kalarnava Tantra«.

Morgenen er helliget koen, der modtager ofre og pyntes med blomster. Derefter dekoreres alle vinduer og d $\varnothing$ råbninger i det nyskurede hus, røgelse afbrændes, og ved mørkets frembrud, tændes utallige lamper både inde og ude.

Omgivet af hele familien, iført sit stiveste puds, udfører familiens overhovede de forskellige offerhandlinger til Lakhsmi. På pengekassen klæbes farvelagte bloktryk af rigdommens gudinde (fig. 5), og foran hendes billede anbringes ofre af penge, frugter og godter. Inkluderet $\mathrm{i}$ disse er nogle morsomme, knald- 
røde og irgr $\varnothing n n e$ sukkerfigurer, som nepaleserb $\varnothing$ rnene, med deres sædvanlige sans for det praktiske, opfatter som gudindens specicelle gaver til dem, og i dagene efter Lakhsmi Puja går samtlige børn i dalen rundt med stærktfarvede læber og tunger, og en lidt usikker fornemmelse i maven.

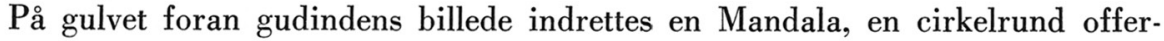
plads inddelt i felter, med fem forskellige kornsorter, fem farver, de otte hellige symboler og krukker med vand. Undertiden erstattes denne af et farvelagt bloktryk, der fremstiller Lakhsmi siddende i midten af en Mandala, omgivet af personer, der frembærer ofre (fig. 6). Dette er, hvad man - alt efter temperament og personlig interesse i sagen - kalder enten »erstatning med et symbol «, eller »fors $\varnothing$ g på at snyde guderne". Hvordan man end bedømmer dette fænomen, er det en almindelig foreteelse fra den grå oldtid til vore dage, og trods alt ikke mindre forståeligt, end at pengesedler betragtes som værende mere værd end det papir, de er trykte på.

Lakhsmi Puja er, som man kan tænke sig, et fors $\varnothing \mathrm{g}$ på at opnå gudindens gunstbevisninger medf $\varnothing$ rende en forbedret $\emptyset$ konomi i det påfølgende år. I uforbeholden fortrøstning om, at det denne gang virkeligt er lykkedes ham at opnå en sikker plads i Lakhsmi's yndest, kaster Nepaleseren sig i samme фjeblik, Puja'en er overstået, ud i de vildeste former for hasardspil, der i de følgende dage og nætter overalt i dalen fortsættes med en udholdende lidenskab, der næres af alles fortrøstning om, at de hver for sig er den nepalesiske Fortunas specielle yndling. Om det nu er fordi Lakhsmi Pujaens ritual ikke er udført med tilstrækkelig omhu, eller fordi der trods alt er en begrænsning på, hvor mange guldstykker selv en rigdommens gudinde er villig til at spendere på sine undersåtter, slutter spillet for mange deltagere med et resultat, der er meget betydeligt ringere end forventningen. Indenfor mands minde er det sket, at en mand ikke alene har spillet sig fra hus og hjem, men at konen, der som et sidste fors $\varnothing \mathrm{g}$ på at opnå gudindens bevågenhed blev givet som indsats, er gået samme vej. Helt så galt går det ikke mere. Man siger nok, at troen kan flytte bjerge, men også i Nepal er der en spirende erkendelse af, at den ikke altid gør det, selv når det synes mest $\phi$ nskværdigt.

Bloktrykket af Lakhsmi (fig. 5) viser resultatet af de elementer, som Nepals nutidskunst er komponeret over. Gudindens sari-kostume er indisk, Kina er repræsenteret ved den lille mand med kineserskæg og mandarinkåbe, medens tronstolens l $\varnothing$ vehoveder og gesvejsninger sammen med stukpillerne i baggrunden genspejler den europæiske klunkestils beklagelige, men ikke desto mindre meget velkomne triumftog gennem Asiens gamle kulturlande. Det rent nepalesiske element, lidt beskedent $\mathrm{i}$ dette tilfælde, er repræsenteret af de to troldagtige dværge, der kaldes Kyat'er, og tilhører den talrige og brogede forsamling af djævle, trolde og spøgelser, der huserer i dalen. I deres hvide form er de venligsindede og hjælper Lakhsmi med at bære de tunge pengeposer. I deres sorte skikkelse er de fulde af overnaturlige kræfter, som de med forkærlighed anvender til menneskehedens fordærv.

Der er adskillige andre bloktryk, knyttet til dalens religiøse liv; men som det her vil være for vidtløftigt at beskrive i detaljer. "Asta Mangal ", de otte lykkesymboler: Srivatsa, Pundarika, Dhoja, Kalasa, Chamar, Matsya, Chhatra og 
Sankha er heldbringende i almindelighed, og tjener derfor indirekte til at holde sig onde ånder fra livet. Til mere direkte angreb på djævelskab og spøgeri benyttes bloktryk af de otte modergudinder, "Asta Matrika «: Mahakali, Babhravi, Brahmayani, Maheswari, Vaisnabi, Kumari, Indrayani og Mahalakhsmi. I forbindelse med disse bruges ofte et bloktryk, der fremstiller Bokhva, hvis frygtindgydende portræt også tages $\mathrm{i}$ anvendelse for at afvende den forestående ulykke, som en død kat eller slange i huset menes at være et sikkert varsel om.

I hårskæringsceremonien, der tjener til at etablere den lille dreng $\mathrm{i}$ hans kaste, benyttes et bloktryk af Chakra Fani, der anbringes på konfirmandens hovede. I meget ung alder bortgiftes de små Newari-piger til en bælgfrugt og opnår herved immunisering overfor enkestandens rædsler under ortodoxe hinduregler, for uanset hvorledes senere indgåede ægteskaber former sig, betragtes dette første symbolske ægteskab som vedvarende gyldigt. Under ceremonien bindes et bloktryk, Mo-ki, på den lille piges hovede, og hun bærer dette gennem det næste døgn.

Hermed har vi i det store og hele omtalt de bloktryk, der stadigvæk er i brug. Der findes imidlertid en del gamle blokke bevarede, som ikke mere anvendes til trykning, men som gennem deres motiver kan henføres til bestemte fester og ceremonier, uden det dog er muligt nu at opspore deres oprindelige funktion $\mathrm{i}$ disse. Aftrykket af en gammel blok fra Bhaktapur gengivet som fig. 7, fremstiller gudinden Durga i kamp med bøffeldjævelen Mahishasura, og der kan derfor næppe herske tvivl om, at dette bloktryk tidligere har været benyttet i forbindelse med den blodige Maha Navami ceremoni, der falder på den lyse halvdels niende dag i Aswin måneden, (i 1958 d. 21. oktober). Newarerne kalder denne religiøse fest Syako Tyako, hvilket betyder: "Dræb så mange, som du kan", en opfordring, som ikke mange sidder overhørig. Festen fejrer Durgas sejr over Mahishasura, og foran de utallige statuer, der repræsenterer denne blodtørstige dame i dalen, nedslagtes et utal af ofre, fortrinsvis bøfler, da disse betragtes som symboler for Mahishasura.

Fig. 8 gengiver aftrykket af en anden gammel blok, som antagelig stammer fra Kathmandu. Vi genkender her den centrale scene, som værende Kija Puja, brodertilbedelsesceremonien, der hvert år afholdes på den 27. dag i Kartic (i 1958 d. 12. november). Den siddende broder modtager mad og drikkeofre fra søsteren, der står foran ham. Oprindelsen og betydningen af denne ceremoni er ikke ganske klar, men man går næppe fejl $\mathrm{i}$ at opfatte den som en parallel til de mange ceremonier livet igennem, og hvoraf den allerede nævnte hårskæringsceremoni er den indledende, som tjener til at konfirmere individets forbindelse med kasten. På tilsvarende måde tjener andre ceremonier til at bekræfte personers andre forbindelser og afhængighedsforhold, i dette tilfælde båndet mellem bror og søster. Samhørsfølelse med gruppen, repræsenteret ved familie og kaste, er et stærkt og gennemgående motiv i dalens liv, som det klart er symboliseret i kasteceremonierne, hvor en lang bomuldstråd passeres gennem alle deltagernes hænder, indtil trådens ender m $\varnothing$ der hinanden. De to skikkelser, der flankerer midterscenen på bloktrykket, lader sig identificere som Yama Dutas, dødsguden Yamas udsendinge. Med våbenet i højre og rebet i venstre hånd, fældes og bindes de udsete ofre og bringes til doms foran dødsguden, men her står de afventende, 


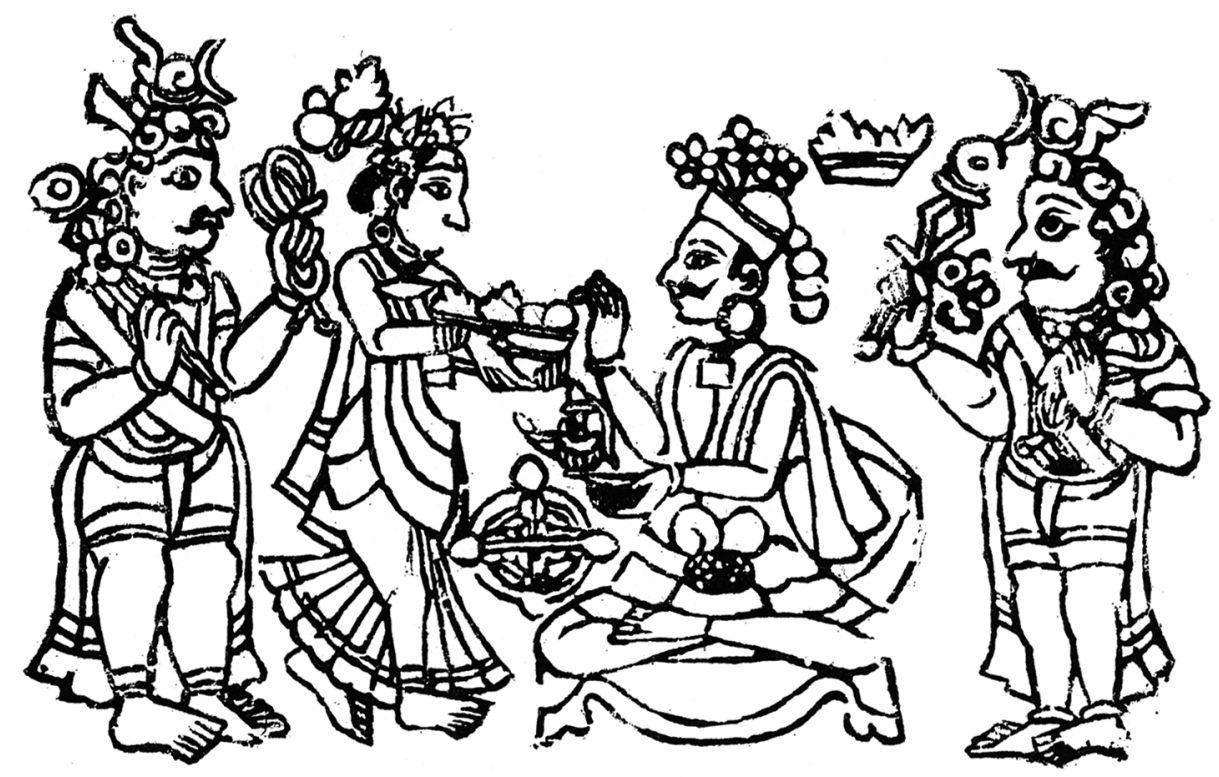

Fig. 8. Kija Puja, brodertilbedelsesceremonien. Aftryk af gommel blok, antagelig fra Kathmandu, $18 \mathrm{~cm} \times 27 \mathrm{~cm}$.

The Kija Puja, the ceremony of brother-worship. Print of an old block, probably from Kathmandu, $18 \mathrm{cms} . \times 27 \mathrm{cms}$.

ude af stand til at forstyrre ceremonien. Måske giver dette billede os en ide om den oprindelige filosofi, der danner grundlaget for samhørsceremoniernes opståen. Det er det ældgamle motiv: "Den snor, der spindes af strenge tre, brister fuldnæppelig«. Sammenhold gør stærk; men den, der står alene, er et let offer for Yamas grådige udsendinge. Denne tydning hviler på formodningernes noget usikre grundlag, men st $\varnothing$ ttes af det forhold, at man til menneskeofringerne udvalgte individer, der frivilligt eller tvunget af omstændighederne var løsrevet fra familie og gruppe, omstrejfere og krigsfanger.

Det står nu tilbage, at beskæftige os lidt med selve bloktrykkene og deres fremstillere. Blokkene skæres af specialister indenfor Urärkasten. Materialet er, med kun een kendt undtagelse, træ. Der synes til tider at have været mangel på anvendeligt træ $\mathrm{i}$ tilstrækkelige store dimensioner, for nogle af de større blokke ses at være sammenføjede af to eller flere stykker, men dette kan naturligvis også være et udslag af sparsommelighed fra blokskærerens side. Det fremgår imidlertid tydeligt, at forklaringen ikke kan være et fors $\varnothing \mathrm{g}$ på at forhindre tvistning af blokken, hvilket forøvrigt ikke optræder som noget problem, da det på grund af trykningsmetoden ikke er af væsentlig betydning om trykfladen er fuldstændig plan.

Lerets betydning for dalens liv er enorm. Vi har allerede omtalt dets vitale rolle som rig næringsbund for agerbruget, men det finder desuden anvendelse indenfor utallige områder, der spænder fra bygningsmateriale til shampoo for kvindernes hår, og det kan derfor ikke forbavse, at den overfor nævnte undtagelse er en trykblok af soltørret ler (fig. 9). Blokkens st $\varnothing$ rrelse er $15,5 \mathrm{~cm} \times 18,5$ 


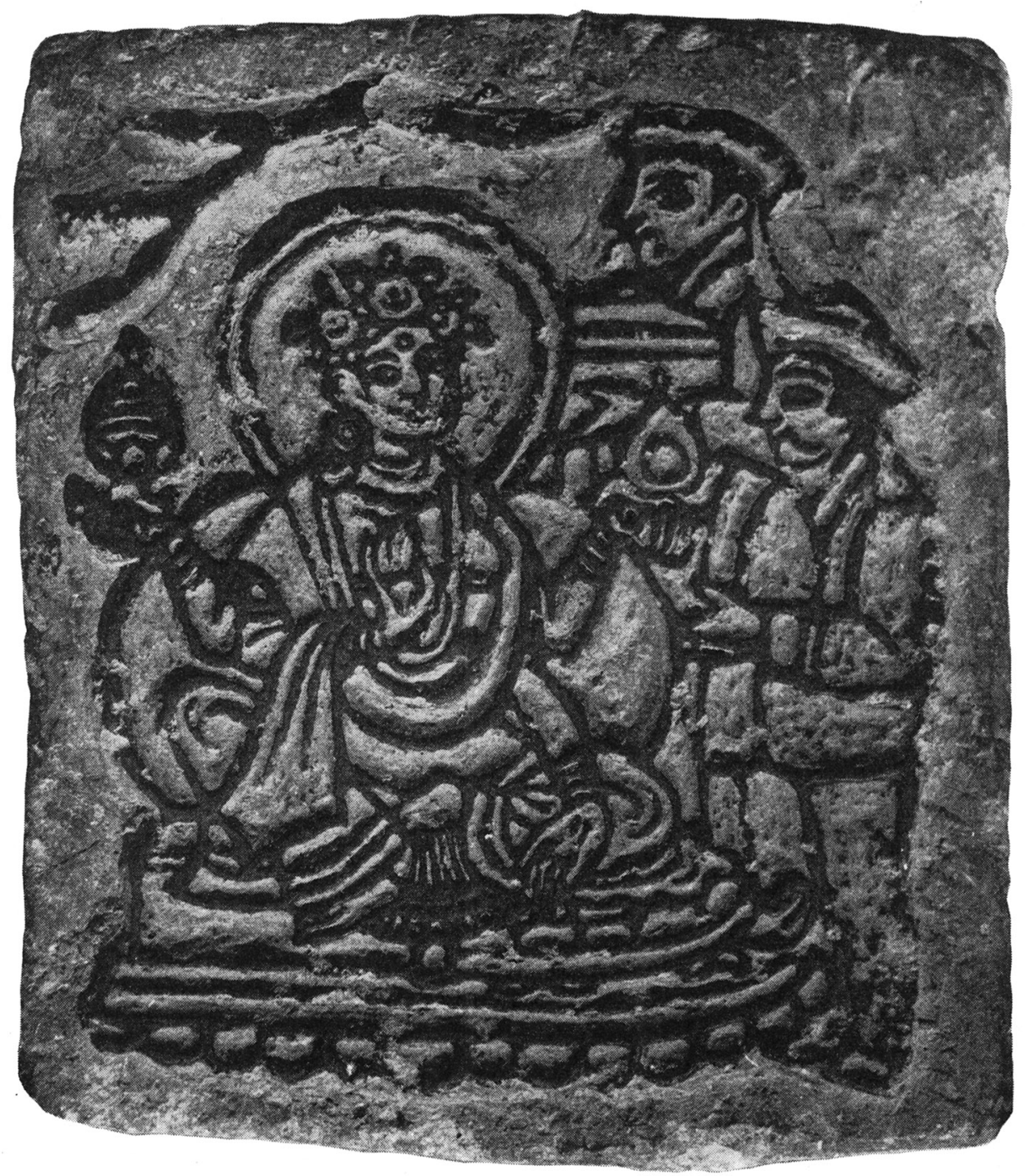

Fig. 9. Gammel trykblok af soltørret ler, antagelig fra Kathmandu. Den fremstiller gudinden Lakhsmi. Old printing block of sun-dried clay, probably from Kathmandu. It represents the goddess Lakhsmi.

$\mathrm{cm}$, tykkelsen $3 \mathrm{~cm}$, dens motiv gudinden Lakhsmi. Som sagt er denne blok et unikum, og det lader sig ikke afgøre, om den repræsenterer en periode, hvor leret blev benyttet som materiale for trykblokkene, eller om den er resultatet af et isoleret eksperiment.

Fra træskæreren går trykblokken til kunstneren, der tilhører kasten Pung. Af hensyn til holdbarhed og styrke lægges den først i oliebad (sennepsfrøolie), hvorefter trykning kan begynde. Tryksværten tilberedes af en blanding af lampesod, gummi arabicum (Saresh på nepali og newari) og vand. Den rette konsistens 
opnås ved en let opvarmning. Blokken anbringes på gulvet med trykfladen opad, og sværten påstryges. Derefter lægges papiret over blokken og afstryges med hånden. Farverne til kolorering af trykket tilberedes på samme måde som tryksværten, kun er de af en letflydende konsistens, der tillader pålægning med pensel. De nu anvendte farvepigmenter er alle indførte kemiske farver, men tidligere anvendtes naturlige plante- og mineralfarvestoffer. Farvelægningen foregår efter »samlebåndsprincippet «, en enkelt farve ad gangen, og kunstneren assisteres her ofte af børnene i familien.

Nogen tid før hver fest eller ceremoni, hvori bloktryk finder anvendelse, begynder man at fremstille et passende oplag, men aldrig større, end hvad man kan regne med vil blive solgt under den kommende fest, for i tiden indtil næste års fest forekommer ikke en eneste salgsmulighed. Dagen f $\varnothing \mathrm{r}$ festen anbringer et medlem af kunstnerens familie sig på gaden omgivet af bundter af bloktryk. Hver type bloktryk tilbydes i regelen i flere variationer, for også den nepalesiske bloktrykker har erfaret, at for at klare sig i konkurrencen, må man have noget for enhver smag, og ikke mindst for enhver pengepung.

Størrelsen af bloktrykkene varierer, som rimeligt er, efter deres anvendelse. De største tryk er Nagabillederne, der bruges til opklæbning på husets facade under Naga Panchami og som er op til $55 \mathrm{~cm} \times 45 \mathrm{~cm}$. Her efter følger i størrelsesorden, kohovederne fra Gaii Jatra ceremonien i Bhaktapur, der når en størrelse af $46 \mathrm{~cm} \times 30 \mathrm{~cm}$, medens de mere beskedne køer i Kathmandu og Lalitpur må nøjes med hoveder på ca. $28 \times 23 \mathrm{~cm}$. Da der jo desværre er en naturlig begrænsning på, hvor stor gennemsnitsfamiliens pengekiste behøver at være, og da igen Lakhsmitrykkene er beregnede til at påklæbes denne, findes disse ikke i kæmpeformat. De største er $21 \mathrm{~cm} \times 17 \mathrm{~cm}$, men de forekommer helt ned til en størrelse på $4 \mathrm{~cm} \times 5 \mathrm{~cm}$, genspejlende hvorledes livets goder er ulige fordelte.

Vi har adskillige gange refereret til bloktrykkeren som "kunstneren", hvilket ikke må opfattes som et fors $\varnothing \mathrm{g}$ på at hæve hans produkter op i et højere plan. Forklaringen er, at bloktrykning kun udgør en gren af hans arbejde. Hans profession er kunstmaler, Chitra Kar; det er ham, der dekorerer djævledanserens maske, processionernes kæmpemæssige paraplyer, bryllupskrukkernes runde buge o. s. v. Hans fremtid er usikker, for i Nepal vil også mekaniske metoder afløse håndens arbejde. Tiden er ikke fjern, hvor bloktrykkeren selv kun vil behøve det mindste, lillebitte billede af Lakhsmi til at klæbe på sin slunkne pengekasse, og det vil endda antagelig være trykt på rotationspresse.

\section{Nepalese Woodcuts.}

Where Nepal is here named it is not to be understood as the land of Nepal as it now appears on the map, but rather the very fertile valley, the largest in the Himalaya, in which lies the capital of the country, Kathmandu. Not only was in earlier days the term Nepal synonymous with the Kathmandu valley, but even to this day the Kathmandu valley, with its urban civilisation, is referred to as Nepal by the surrounding mountain peoples.

It should be said at once that the woodcuts are by no means a valid example of the excellence of Nepalese craftsmanship. They represent rather its lowest level, and the reason for their treatment here is first and foremost that they are faced with an imminent defeat and 
complete disappearance in the struggle with modern printing machines. And secondly that they present a living picture of the religious life which is unfolded among the ordinary people of the Kathmandu valley.

With but few exceptions the woodcuts are associated with religious festivals and ceremonies, and a description of some of the most important of these will therefore now be given.

The Buddhist scripture "Kriya Samuchchaya" records the saying of the Buddha, "Worship the Nagas, and also Varuna, on the fifth day in the lighter half of Srawan. This counteracts all devilry occasioned by snakes and promotes a plentiful rainfall!" The written authority of the Hindus is the "Garuda Tantra", in which Vishnu commands, "Paste with cow manure pictures of the Nagas over the entrance to the house and over the other doors of the house on the fifth day of the lighter half in the month of Srawan, and worship the snakes in accordance with the ritual prescribed."

In agreement with these commands this "day of the snakes" is observed by Hindus and Buddhists alike, and coloured woodcuts, large and small, representing the Nagas, the snakes, are pasted up over the house entrance and the other doors. This type of block printing is here represented by Fig. 1, an original woodcut showing Kanya Nagini, the snake virgin, a particularly popular subject within this group of woodcuts. The popularity of this figure is undoubtedly due to the fact that she is the counterpart, in the world of the snakes, to Kanya Kumari in the world of men. And Kanya Kumari is particularly widely worshipped in Nepal. She is the divine virgin, an aspect of Parvati, and in Nepal is represented by several living personifications, of whom the deadly serious little Kumari who resides in her own palacetemple opposite the old royal palace in the centre of Kathmandu is regarded as the most distinguished. After a somewhat brutal process of selection each new Kumari is installed, normally at an age of 5-6, and retains her divine position until the commencement of puberty, when a new Kumari is selected.

The Sanskrit text on the woodcut, Fig. 1, is a somewhat abbreviated form of a standard text which normally, either in full or abridged, occurs on the Naga prints. After a prefacing invocation of Ganesha, the elephant god, which normally introduces religious texts, the inscription reads in its complete form: "The saints Agastya, Pulastya, Vaisampayam, Sumanta and Jaimini are the five protectors of the thunderbolt. There are eight Nagas, whose names are Ananta, Vasuki, Padma, Mahapadma, Tahshaka, Kulika, Karkotaka and Sankha."

According to the "Vishnu Purana", Kadru, one of Kasyapa's thirteen wives and a granddaughter of Brahma, was the mother of a thousand multi-headed snakes, who were organised under twelve chieftains. Other texts, like ours, name eight important Nagas. The companies of the snakes inhabit the underworld, the seas and the lakes, together with scorpions, centipedes and other crawling things.

Hindu mythology is full of legends of the power and cunning of the Nagas, whom it is best to keep on good terms with, and for the dwellers in the Kathmandu valley the myths have a particularly awesome immediacy. For in the local "Swayambhu Purana" it is told that the lake, which in former days filled the valley, was the home of Karkotaka Naga and many other snakes. The Nepalese therefore live in constant awareness of having driven these dangerous creatures from a well-loved dwelling place, and it is consequently necessary for them to make special efforts to reestablish good relations.

As is natural where a numerous population lives within a very limited agricultural area, the food situation within the valley is the problem which overshadows all else. As the text quoted above from the "Kriya Samuchchaya" suggests, the Nagas, if not placated, are likely to attack at the weakest point, to cut off the lifegiving rainfall. And against this background it is hardly surprising that in the light half of the month of Srawan there is a great demand for the woodcuts representing the various Nagas, and that on the fifth day, as the old scriptures prescribe, they are pasted up with care over every door.

In this nationwide exhibition of snake portraits the popular hero-god Krishna is often to be seen. As so often when human freedom is in danger, he comes to the rescue. With his flute he charms the eight deadly snake-kings who, united in a rigid geometrical pattern, cancel out each other's powers and become thereby powerless to harm mankind. This scene is here represented in the beautiful woodcut reproduced as Fig. 2.

Throughout the year the gate to the Nepalese heaven, Yama Dwar, remains closed, and 
it may be believed that among the gradually increasing number of the dead who wait outside that one day in the year when the door stands a little ajar is looked forward to with eager anticipation. That day falls on the first day of the dark half of the month of Srawan (in 1958 the 30th August).

Unfortunately for the dead, the door does not open enough for them to pass through, and experience shows that only the cow it able to push back the heavy door with its horns. It is to help here that the ceremony of Gaii Jatra (Sa-Paru in Newari) is observed on this day. Every family in which a death has taken place during the past year sends a cow, or one of the family decked out as a cow, to help the dead into heaven.

For the masquerade in Kathmandu a headdress is used consisting of a flat woven basket bearing on the front a coloured woodcut of a cow's head (Fig. 3) and on the back a woodcut of Ganesha (Fig. 4). On either side of the headdress there is a thin wooden or bamboo upright bearing coloured paper flags and fan-like decorations, while on the basket is attached a group of three miniature cow's horns of woven straw. The disguised person draws behind him a long cloth train, on which gifts to the dead in the form of fruit and cakes are placed. In Kathmandu Gaii Jatra is held as a private family festival, and separate processions of men dressed as cows, or in the case of the richer families actual cows, wend through the streets accompanied by flute and drum. In Lalitpur (Patan), on the other hand, all participants unite in one large procession and set off to the assistance of the dead accompanied by many orchestras; and here the "cows" pull in their train pots and pans and other household goods.

Of all the many motives treated in the Nepalese woodcuts the cow's head for the Gaii Jatra ceremony is of the highest decorative effect (Fig. 3). The block is cut with clear powerful lines, and the colouring is carried out with a sure feeling for dramatic combination. That we find the elephant god, Ganesha, (Fig. 4) taking part in this ceremony should not surprise us, for the son of Siva and Parvati is ubiquitous in Nepal. No festival is held, no ceremony celebrated without his participation. And nowhere can his assistance be more desirable than when it is a question of helping a dear, but not necessarily deserving, departed in through the heavenly portals. For Ganesha, the god of wisdom, is also the overcomer of obstacles.

It is said, and not entirely without reason, that in Nepal every day of the year has its own festival or ceremony. But surely no event is anticipated with more unmixed pleasure than the yearly ceremony in honour of the goddess of wealth, Lakhsmi. For Lakhsmi Puja is a true festival, free of the nagging apprehension of the Naga Panchami, the melancholy recollections associated with the Gaii Jatra, or the macabre and expensive aspects of the festivals demanding blood sacrifices.

The morning is sacred to the cow, which receives offerings and is adorned with flowers. Thereafter all windows and doors in the newly cleaned house are decorated, incense is burnt, and at nightfall innumerable lamps are lit inside and out.

Surrounded by the entire family in its finest clothes, the head of the family carries out the various rituals of offering to Lakhsmi. Coloured woodcuts of the goddess of wealth (Fig. 5) are pasted on the cashbox, and before her picture are placed offerings of money, fruit and sweets. Included among these are various amusing figures of sugar, bright red or green, which the Nepalese children, with their usual practical good sense, interpret as special gifts to themselves from the goddess. And in the days following the Lakhsmi Paja every child in the valley goes around with violently coloured tongue and lips, and with a somewhat uncertain feeling in its stomach.

On the floor in front of the picture of the goddess a Mandala is formed, a circular place of offering divided into sections containing five different sorts of corn, five colours, the eight holy symbols and vases of water. Sometimes a coloured woodcut (Fig. 6) is substituted for this, showing Lakhsmi sitting in the centre of a Mandala, surrounded by persons bringing offerings. This is what - depending on temperament or ones personal interest in the matter is called "symbolical substitution" or "trying to cheat the gods". However it be judged it is a procedure common enough all the way from gray antiquity up to our own day, and is after all no less understandable than the view that paper money is worth more than the paper on which it is printed. 
The woodcut of Lakhsmi (Fig. 5) illustrates the elements of which modern Nepalese art is composed. The sari in which the goddess is clothed is Indian, China is represented by the little man with Chinese beard and mandarin cloak, while the lions' heads and ornamentation of the throne and the stucco pillars in the background reflect the triumphal progress, regrettable but enthusiastically welcomed, of the European Victorian style through the ancient culture lands of the East. The purely Nepalese element, somewhat unpretentious in this case, is represented by the two gnome-like dwarfs, who are called Kyats and belong to the numerous and variagated families of dwarfs, trolls and ghosts who inhabit the valley. In their white form they are friendly disposed and help Lakhsmi to carry the heavy moneybags. But in their black shape they are full of supernatural powers which they use with zeal for the ruin of mankind.

We have now to a great degree described the woodcuts which are still in use. A large number of old blocks are, however, preserved which are no longer used for printing, but whose motifs can be ascribed to definite festivals and ceremonies, although it is no longer possible to trace their original function in these ceremonies. The cut of an old block from Bhaktapur, reproduced as Fig. 7, shows the goddess Durga struggling with the buffalo-demon Mahishasura, and it can hardly be doubted that this woodcut was originally used in connection with the bloody ceremony of Maha Navami, which falls on the ninth day of the light half of the month of Aswin (in 1958 the 2lst October). The Newars call this festival Syako Tyako, which means "Kill as many as you can", an invitation which few ignore. The festival celebrates the victory of Durga over Mahishasura, and before the numerous statues in the valley of this bloodthirsty lady are sacrificed innumerable victims, preferably buffaloes, as they are regarded as symbols of Mahishasura.

Fig. 8 reproduces a cut from another old block, probably from Kathmandu. We recognise here the central scene as the Kija Puja, the brother-worship ceremony which is held each year on the 27th day of Kartic (in 1958 the 12th November). The seated brother accepts offerings of food and drink from the sister standing before him. The origin and significance of this ceremony is obscure, but it would seem to be a parallel to the many ceremonies which serve to confirm the connection between the individual and the caste. In a similar way other ceremonies serve to emphasize other connections and relationships of the individual, in this case the bond between brother and sister. The feeling of belonging to a group, represented by the family and the caste, is a strong and ubiquitous motif in the life of the valley, clearly symbolized in the caste ceremony, where a long cotton thread is passed through the hands of all the participants, until the ends of the thread meet again. The two figures flanking the central scene of the woodcut can be identified as the Yama Dutas, the emissaries of Yama, the god of death. With weapon in the right hand and rope in the left they bind the victim and bring him to judgment before the god, but here they stand waiting, powerless to disturb the ceremony. This may give us some idea of the original thought behind the symbolism: unity is strength, but he who stands alone is an easy prey for the greedy messengers of Yama. This interpretation rests on a somewhat uncertain basis, but is supported by the fact that individuals were chosen as human sacrifices who, voluntarily or involuntarily, were separated from their families or relationship groups, vagabonds and prisoners of war.

It now remains to deal briefly with the actual woodcuts and their producers. The blocks are cut by specialists of the Urär caste, and the material is, with only one known exception, wood. There would appear at times to have been a shortage of suitable wood of sufficiently large size, for some of the larger blocks can be seen to have been put together from two or more pieces, but this may also be the result of economy on the part of the block cutter. The construction shows that the explanation for this practice cannot have been a desire to prevent the block from warping, and in any case warping presents no problem, as the method of printing does not require that the printing surface be exactly plane.

The importance of clay in the life of the valley is enormous, and it is used, not merely as a basis for agriculture, but for a variety of purposes extending from building material to shampoo for the women's hair. It can therefore occasion no surprise that the exception mentioned above is a printing block of sun-dried clay (Fig. 9). The size of the block is $15.5 \times$ $18.5 \times 3$ cms., its motif the goddess Lakhsmi. It is a unique specimen, and it cannot be 
determined whether it is the result of an isolated experiment or whether it represents a period when clay was used generally as a material for blocks.

From the wood carver the printing block goes to the artist, who belongs to the Pung caste. To preserve its strength and durability it is given a bath in oil (of mustard seed) before printing commences. The printing ink is made from a mixture of lamp-soot, gummi arabicum (saresh in Nepali and Newari) and water, the correct consistency being obtained by a slight warming. The block is placed on the floor with the printing surface uppermost, and the ink brushed on. The paper is then laid over the block and smoothed over with the hand. The paints for colouring the print are prepared in the same way as the printing ink but are of a more fluid consistency to allow of application with a brush. The pigments now used are all imported chemical colours, but originally natural vegetable and mineral pigments were employed. Colour application is carried out on the "assembly-line" principle, one colour at a time, and here the artist is often assisted by the children of the family.

Some time in advance of each festival or ceremony for which the woodcuts are used the artists begin to manufacture an appropriately large edition, never larger than they estimate can be sold in the course of the coming festival, for from then until the following year's festival there will be no possibility of further sale. The day before the festival members of the artist's family station themselves on the street surrounded by bundles of the print. Each type of woodcut is normally offered for sale in a number of variations, for even the Nepalese block printer has learnt by experience that to succeed in a competitive society they must have something for every taste, and not least for every purse.

The size of the woodcuts varies, as would be expected, according to their use. The largest prints are the Naga pictures, which are to be pasted on the house facades during the Naga Panchami. They measure up to $55 \times 45 \mathrm{cms}$. Next in order of size come the cows heads for the Gaii Jatra ceremony in Bhaktapur, which reach a size of $46 \times 30 \mathrm{cms}$., while the more modest cows in Kathmandu and Lalitpur must be content with heads of about $28 \times 23 \mathrm{cms}$. As there is unfortunately a natural limit to the size required for the cashbox of the average family, and as the Lakhsmi prints are designed to be pasted upon these, the prints for this ceremony do not occur in large format. The largest are $21 \times 17 \mathrm{cms}$., but they are found in all sizes down to $4 \times 5 \mathrm{cms}$., which reflects the uneven distribution of this world's goods.

We have several times referred to the block printer as an "artist". This must not be understood as an attempt to raise his products to a higher plane. The explanation is that block printing is only a branch of his work. His profession is that of artist, Chitra Kar. He it is who decorates the masks of the devil dansers, the gigantic umbrellas of the processions, the round sides of the marriage jars, and many other objects of ceremonial use. His future is uncertain, for also in Nepal will mechanical methods take the place of the ancient craftmanship. The time is not far distant when the block printer himself will only have need for the very smallest of the pictures of Lakhsmi to paste upon his shrunken cashbox, and even that will probably have been produced upon a rotation press.

Werner Jacobsen,

Danish Research Institute, Kathmandu, Nepal. 